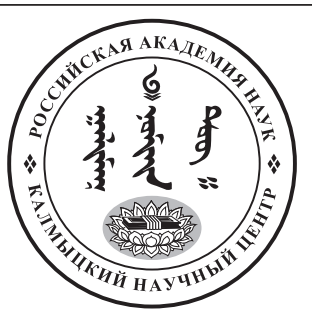

Published in the Russian Federation

Oriental Studies (Previous Name: Bulletin of the Kalmyk Institute

for Humanities of the Russian Academy of Sciences)

Has been issued as a journal since 2008

ISSN: 2619-0990; E-ISSN: 2619-1008

Vol. 13, Is. 6, pp. 1579-1593, 2020

DOI: $10.22162 / 2619-0990-2020-52-6-1579-1593$

Journal homepage: https://kigiran.elpub.ru

УДК 930

DOI: $10.22162 / 2619-0990-2020-52-6-1579-1593$

\title{
Газетные фотографии: использование приема гиперболизации (на материале публикаций в газете «Хальмг үнн» («Калмыцкая правда») в 1957-1961 гг.)
}

\author{
Виктория Васильевна Куканова ${ }^{1}$, Александра Тагировна Баянова², \\ Лариса Бадмаевна Манджикова
}

${ }^{1}$ Калмыцкий научный центр РАН (д. 8, ул. И. К. Илишкина, 358000 Элиста, Российская Федерация) кандидат филологических наук, ведущий научный сотрудник, директор

iD 0000-0002-7696-4151.E-mail: vika.kukanova@gmail.com

${ }^{2}$ Калмыцкий научный центр РАН (д. 8, ул. И. К. Илишкина, 358000 Элиста, Российская Федерация) заведующий, младший научный сотрудник

iD 0000-0001-7718-802X. E-mail: ale-bayanova@yandex.ru

${ }^{3}$ Калмыцкий научный центр Российской академии наук (д. 8, ул. И. К. Илишкина, 358000 Элиста, Российская Федерация).

младший научный сотрудник

0000-0003-3902-2664. E-mail: 0862larisa@gmail.com

Аннотация. Введение. Фотография является визуальным источником информации, уникальность которого была осознана разными исследователями. Фотографии, публикуемые в газетах, самом оперативном виде печатных изданий середине прошлого века, отражая повседневную жизнь, в целом передавали дух эпохи. Целью данной работы является анализ «содержания» фотографий за период 1957-1961 гг. в газете «Хальмг үнн» («Калмыцкая правда») — на протяжении более столетия главным периодическим изданием в республике, в котором публиковались и продолжают публиковаться материалы на языке титульного народа — на калмыцком. Материалы и методы. Методом сплошной выборки были отобраны фотографии из газеты «Хальмг үнн» («Калмыцкая правда») за период 1957-1961 гг. В результате были привлечены более 4 тысяч фотографий для анализа, однако в фокусе нашего исследования находятся прежде всего снимки, сделанные местными фотографами и на территории Калмыцкой АССР. Фотографии ТАСС привлекались для отслеживания одинаковых тенденций, сравнения и сопоставления с региональными фотографиями. Bblвoды. Исследование показывает, что фотоматериалы на страницах газеты «Хальмг үнн» («Калмыцкая правда») отражают смешение стиля социалистического реализма и сурового стиля. В фокусе внимания фотожурналистов оказалась жизнь рядовых тружеников, не являвшихся представителями партии и власти, прежде всего ее рабочие моменты. В анализируемых фотосюжетах несомненно влияние эпохи 
Н. С. Хрущева. За первые два года рассматриваемого периода фотография в калмыцкой прессе совершенствовалась в ускоренном темпе, редакционные фотографы быстро осваивали известные на тот момент в советской фотожурналистике приемы. Например те, с помощью которых достигалась гиперболизация изображаемого на снимках, востребованная советской идеологией. Гиперболизация достигалась съемкой с использованием определенных ракурсов, с помощью широкоугольного объектива и насадочных линз. Подобный анализ газетного материала необходимо продолжать в рамках изучения развития как региональной прессы, так и источника для антропологических исследований.

Ключевые слова: газета, фотография, визуальный источник, гипербола, фотожурналистика Благодарность. Исследование проведено в рамках госзадания № АААА-А19-1 19090590086-0 (сбор, оцифровка материала) и при финансовой поддержке гранта в № 075-15-2019-1879 в форме субсидии из федерального бюджета, выделяемой для государственной поддержки научных исследований, проводимых под руководством ведущего ученого (подготовка статьи). Для цитирования: Куканова В. В., Баянова А. Т., Манджикова Л. Б. Газетные фотографии: использование приема гиперболизации (на материале региональной прессы 1957-1961 гг.) // Oriental Studies. 2020. T. 13. № 6. C. 1579-1593. DOI: 10.22162/2619-0990-2020-52-6-1579-1593

UDC 930

DOI: $10.22162 / 2619-0990-2020-52-6-1579-1593$

\title{
Hyperboles in Newspaper Photographs: A Case Study of Khalmg Ünn's ('The Kalmyk Pravda') Issues, 1957-1961
}

\author{
Viktoriya V. Kukanova ${ }^{1}$, Aleksandra T. Bayanova ${ }^{2}$, Larisa B. Mandzhikova ${ }^{3}$ \\ ${ }^{1}$ Kalmyk Scientific Center of the RAS (8, Ilishkin St., Elista 358000, Russian Federation) \\ Cand. Sc. (Philology), Leading Research Associate, Director \\ iD 0000-0002-7696-4151. E-mail: vika.kukanova@gmail.com
}

${ }^{2}$ Kalmyk Scientific Center of the RAS (8, Ilishkin St., Elista 358000, Russian Federation) Head of the Alekseeva Scientific Library and Archive, Junior Research Associate

iD 0000-0001-7718-802X. E-mail: ale-bayanova@yandex.ru

${ }^{3}$ Kalmyk Scientific Center of the RAS (8, Ilishkin St., Elista 358000, Russian Federation) Junior Research Associate

iD 0000-0003-3902-2664. E-mail: 0862larisa@gmail.com

\author{
(C) KalmSC RAS, 2020 \\ (C) Kukanova V. V., Bayanova A. T., Mandzhikova L. B., 2020
}

\begin{abstract}
Introduction. Photography is a visual source of information, and its unique character has been recognized by numerous researchers. Newspaper photographs tend to mirror both a historical era proper and daily life of its inhabitants. Goals. The paper aims at analyzing the 'essential messages' of photographs published by Khalmg Ünn ('The Kalmyk Pravda') newspaper in 1957-1961. The periodical is an ethnic-oriented print media to have published — and still does — Kalmyk language materials. Materials and Methods. The continuous sampling method was employed to extract photographs from newspaper issues of 1957-1961. So, a total of 4,000 units were analyzed, but the study primarily focuses on pictures that were taken by local photographers in the territory of the Kalmyk ASSR. Photographs by TASS were involved to trace similar trends through comparison with regional photographic images. Conclusions. The study shows that photographic materials of Khalmg Ünn ('The Kalmyk Pravda') highlight different artistic trends manifested in the eclectic patterns compiled from both Socialist realism and the 'severe style' (the latter characterized by romantic
\end{abstract}


heroification of strenuous laborers). Just in two years the newspaper images rapidly evolutionized from mere shots to photographic pictures created through the use of diverse means and methods, e.g., that of hyperbolization achieved via different camera angles and glass prism techniques. Newspaper photographers turned to common laborers to show their joys and hardships, everyday life of citizens not involved in party or any other administrative activities. The Khrushchev era gave rise to most essential changes in newspaper photography and the images examined. Further analysis of newspaper materials shall facilitate the development of both regional print media and anthropological studies at large.

Keywords: newspaper, photograph, visual source, hyperbole, photojournalism

Acknowledgements. The reported study was funded by state assignment no. AAAA-A19-119090590086-0 (collection of materials, digitalization) and government grant no. 07515-2019-1879 in the form of federal budget subsidy aimed to support scientific research directed by the Leading Scientist (preparation of an article).

For citation: Kukanova V. V., Bayanova A. T., Mandzhikova L. B. Hyperboles in Newspaper Photographs: A Case Study of Khalmg Ünn's ('The Kalmyk Pravda') Issues, 1957-1961. Oriental Studies. 2020. Vol. 13(6): 1579-1593. (In Russ.). DOI: 10.22162/2619-0990-2020-52-6-1579-1593

\section{है}

\section{Введение}

Фотография как явление визуальной культуры стала в последнее десятилетие объектом исследовательского интереса как антропологов, так и социологов, при этом вопрос о времени зарождения визуальной антропологии достаточно спорный. Так, например, Е. С. Данилко задается вопросом: «откуда начинать эту историю, с конца 1990-х, когда сакральное словосочетание „визуальная антропология“ вошло в наш исследовательский лексикон, или удревнить ее до послереволюционных 1920-х, когда появилась советская ,этнографическая фильма“"?» [Данилко, Александров 2020: 8-9]. Тот же самый вопрос можно задать о фотографии как материале для исследования повседневности и этнографических вопросов. Откуда начинать отчет: с конца 1990-х гг. или с момента изобретения фотографии? Ведь и фотографии конца XIX - начала XX в. представляют материал для исследований тех или иных научных проблем. Достаточно вспомнить, что помимо этнографического кино были еще и этнографические снимки, когда пытались через «неподвижную картинку» передать информацию о культуре того или народа.

Фотография прошла в своем развитии сложный путь, который во многом был обусловлен и развитием ее технических возможностей, и, несомненно, идеологией и «модой» той или иной эпохи. Еще в конце XIX - начале XX в. фотоаппарат был ред- костью, и людям приходилось делать снимки в специализированных ателье, что было достаточно дорого (не каждая семья могла себе позволить эту роскошь). С конца XX в. фотосъемка стала обычным, абсолютно доступным процессом, когда можно в любое время взять в руки мобильный телефон и запечатлеть или, как говорят, «остановить» мгновенье.

Создавая газетный корпус калмыцкой региональной прессы ${ }^{1}$, мы обнаружили большое количество фотографий, опубликованных в региональных изданиях, что натолкнуло на мысль об исследовании газетной фотографии ${ }^{2}$ как источника визуальной антропологии. При своей несомненной специфике фотографии, публикуемые в печати в рассматриваемый период, имели черты некоторого сходства с любительскими. Так, и те и другие с середины XIX в. и, пожалуй, до конца XX в. были отнюдь не спонтанными, а постановочными в общей своей массе ${ }^{3}$. Конечно, очевидно, что интенция профессиональной и любительской фотографии различна. Важное отличие фо-

${ }^{1}$ См. Газетный корпус Калмыкии [электронный ресурс] // URL: http://biliq.ru/ethnography/ (дата обращения: 01.09.2020).

${ }^{2}$ См., например, опубликованную работу: [Куканова и др. 2019].

${ }^{3}$ Очевидно, что среди любительских фотографий второй половины XX в. можно найти такие, которые будут обладать той или иной степенью спонтанности, но, как правило, их немного. 
тографий, публикуемых в газетах, от любительских заключалось в более профессиональном исполнении. Однако, если относительно одних (например, столичных) газет можно утверждать, что среди сотрудников был, как минимум, один профессиональный фотограф, для других же, большей частью на должность фотокорреспондентов зачастую принимали тех, кто более или менее умел фотографировать, профессионалов просто не было. В 1957 г., когда калмыки вернулись из мест ссылки, приходилось создавать с нуля многое, в том числе и осваивать новые профессии. Мы предполагаем, что калмыков, как репрессированных, в местах ссылки не допускали к работе в столь важной сфере, как средства массовой информации, поскольку советская власть понимала, что они обладают огромными возможностями манипулирования сознанием. Наше предположение строится на рассказах ссыльных калмыков о негласном запрете 4 работать преподавателями истории ${ }^{5}$ в силу того, что они могли в своей работе воздействовать на сознание детей [Алексеева 2019: 50; Очиров 2019: 27; Гучинова 2019: 414]. Следует отметить, что профессиональных фотографов не хватало во всей стране, редакции газет, журналов жаловались на «кадровый голод». Так, например, Л. В. Семова пишет в своей работе по истории фотожурналистики, что «на тот момент (на 1957 г. - уточнение К. В., Б. А., М. Л.) ни одно из учебных заведений не готовило кадры по специальности „фотография“» [Семова 2016: 13].

Целью данной работы является анализ «содержания» фотографий за период 19571961 гг. в газете «Хальмг үнн» («Калмыцкая правда») — главном общественно-политическим издании в республике, выпускаемом

${ }^{4}$ Такой же запрет существовал на учебу по специальности юриспруденция [Убушиева 2013: 50].

5 Хотя все же исключения из правил были, видимо, многое зависело от политики местных властей. Так, например, известный в республике археолог, этнограф У. Э. Эрдниев с 1944 г. по 1946 г. преподавал историю в школе, затем был принят на работу старшим преподавателем по курсу истории и археологии, одновременно он являлся деканом исторического факультета Новокузнецкого педагогического института, далее старшим преподавателем Кемеровского педагогического института [Кольцов 2005: 36]. на калмыцком языке - языке титульного народа.

\section{Материалы и методы}

Методом сплошной выборки были рассмотрены фотографии из газеты «Хальмг үнн» («Калмыцкая правда») за период 1957-1961 гг., при этом анализировались не только локальные фотографии, но и те снимки, которые направлялись «центром» (ТАСС) для опубликования в средствах массовой информации ${ }^{6}$. В результате были привлечены более 4 тысяч единиц для анализа, однако в фокусе нашего исследования находятся прежде всего фотографии, сделанные местными фотографами и на территории Калмыцкой АССР. Фотографии ТАСС привлекались для отслеживания одинаковых тенденций, сравнения и сопоставления с региональными фотографиями. Следует оговорить, что в библиотеке КалмНЦ РАН отсутствует подшивка за второе полугодие 1959 г., в условиях пандемии и действия ограничительных мер посетить Национальную библиотеку им. АмурСанана не представлялось возможным, тем не менее считаем, что объем выборки достаточный, чтобы проводить качественные исследования, связанные с анализом содержания фотографий. В качестве методов исследования применяются метод анализа фотографий на различных уровнях, контент-анализ. Техническое качество изучаемых фотографий различно: часть из них четкие, с хорошей ретушью, часть - с бледным, размытым изображением. Систематизация и анализ эмпирического материала позволяет по-новому взглянуть на исследуемый материал.

\section{Общая характеристика}

В содержании публикуемых в «Хальмг үнн» фотографий в рассматриваемый период заметен рост идеологической составляющей. Если в 1957-1958 гг. на страницах газеты еще присутствуют снимки, которые отражают в той или иной степени непосредственность впечатления, по которым можно предположить «спонтанность» съемки, то

${ }^{6}$ Надо отметить, что количество фотографий, присланных ТАСС, стало увеличиваться с 1958 г. Если в 1957 г. было всего 5 ед., то в 1958 г. — 196 ед. , а в 1959 г. — уже 611 ед. [Куканова и др. 2019: 1111, табл. 1]. 
в последующие годы влияние цензуры все более явственно проявляется в отборе фотографий с определенным идеологическим наполнением.

В подшивке газеты за указанный период можно найти фотографии, в которых ярко отражена этничность народа. Это снимки, герои которых одеты в национальные костюмы [Хальмг үнн 1957: № 37 (2870); Хальмг үнн 1958: № 40 (3024), № 134 (3118); Хальмг үнн 1959: № 232 (3474), № 236 (3478); Хальмг үнн 1960: № 106 (3603), № 218 (3715)], играют на национальных инструментах [Хальмг үнн 1957: № 17 (2850); Хальмг үнн 1958: № 75 (3059); № 126 (3110); Хальмг үнн 1959: № 211 (3453), № 228 (3470); Хальмг үнн 1960: № 102 (3599); Хальмг үнн 1961: № 125 (3878)]. Есть фотоочерки о мероприятиях, связанных с национальными традициями (конкурсы, спортивных состязания (например, национальная борьба): [Хальмг үнн 1958: № 85 (3069), № 158 (3164), № 181 (3165); Хальмг үнн 1960: № 130 (3484), № 149

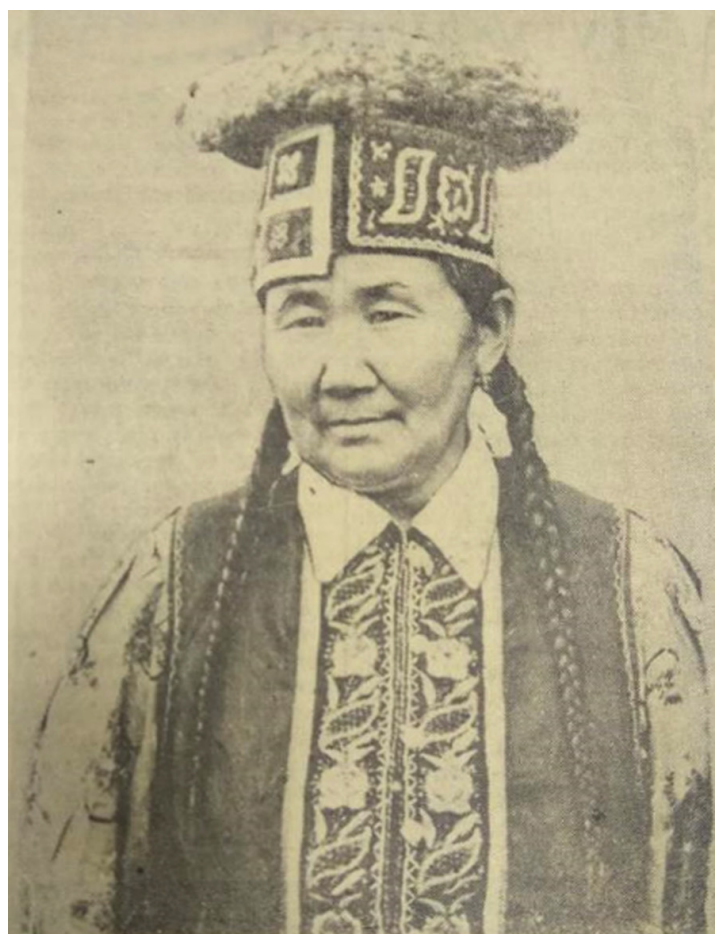

Фото 1. Художница П. И. Емчегирова (в источнике отсутствуют указание на авторство и подпись) [Хальмг үнн 1961: № 167 (3921)]

[Photo 1. Painter P. Emchegirova]
(3646), № 177 (3674), № 191 (3688); Хальмг үнн 1961: № 73 (3827), № 87 (3841), № 176 (3930)]. В 1961 г. встречается всего одна фотография, где дается крупным планом фотография художницы П. И. Емчегировой в национальном костюме, которая увлекалась их шитьем [Батырева 2020: 1382] (см. фото 1), хотя другие фотографии, где отражается элементы этнической идентичности, присутствуют, но уже единично.

Фотокорреспонденты в основном были любителями, среди них никто не имел профессиональных навыков, однако уровень многих фотографий был достаточно высоким. Следует назвать фамилии фотокоров тех лет: Б. Асанов, Р. Астахова, С. Ахремин, И. Ашихмин, А. Балакаев, Н. Будников, А. Вутеро, Б. Манджиев, О. Манджиев, И. Новосельцев, Е. Поваляев, Е. Шарапов, В. Эрдниев и др. ${ }^{7}$ В конце 1950-х - начале 1960-х гг. передвижение по республике было еще крайне затруднительным, поэтому, добравшись до отдаленных населенных пунктов, фотографы старались сделать по

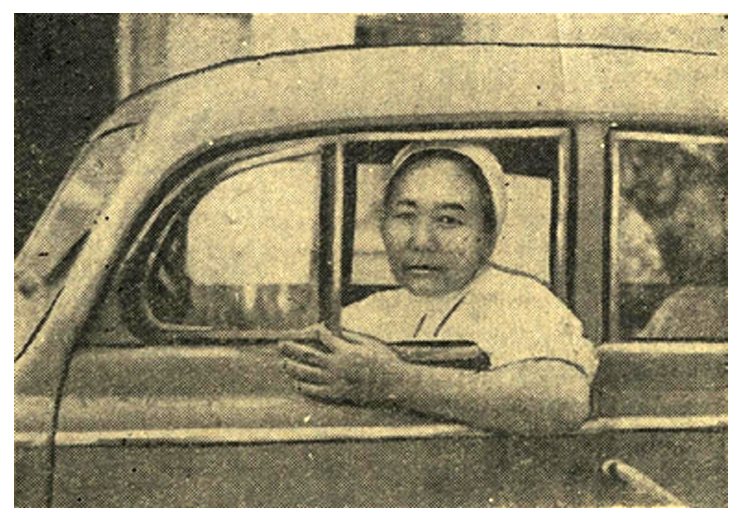

Фото 2.1. [ЗУРГТ: таңгчин больницин диетсестра Булһн Манджиевна Берденова. Автор неизвестен $^{8}=$ На снимке: диетсестра ${ }^{9}$ республиканской больницы Булгн Манджиевна Берденова ${ }^{10}$ ] [Хальмг үнн 1958: № 91 (3075)]

[Photo 2.1. Bulgn M. Berdenova, a dietitian at the Republican Hospital]

${ }^{7}$ Некоторые из них впоследствии стали известными писателями, например А. Балакаев, Е. Поваляев.

8 Здесь и далее орфография и пунктуация подписей к фотографиям приведены к нормам современного калмыцкого языка.

${ }^{9}$ Медицинская сестра по диетическому питанию.

10 Здесь и далее перевод авторов статьи. К. В., Б. А., М. Л. 


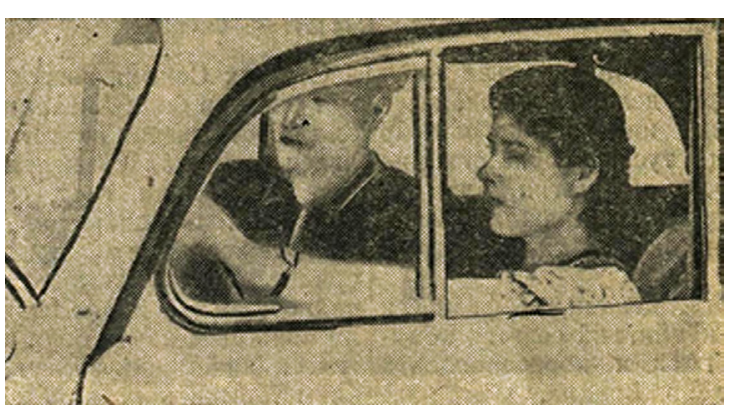

Фото 2.2. Башантинск селәнә эдл-ахун техникумд бүрдәгдсн шофермүдин курст 58 күн сурч hарв, теднәс 32-нь күүкд. ЗУРГТ: Мария Иващенко маши залдж йовна. А. Балакаевин фото = На открытых на базе Башантинского сельскохозяйственного техникума курсах шоферов выучилось 58 человек, в числе которых 38 девушек. На снимке: Мария Иващенко водит машину. Фото А. Балакаева [Хальмг үнн 1958: № 131 (3115)]

[Photo 2.2. Maria Ivashchenko, a driving course attendee. Bashanta Agricultural College hosts driving courses attended by 58 citizzens, including 38 young women. Photo by A. Balakaev]

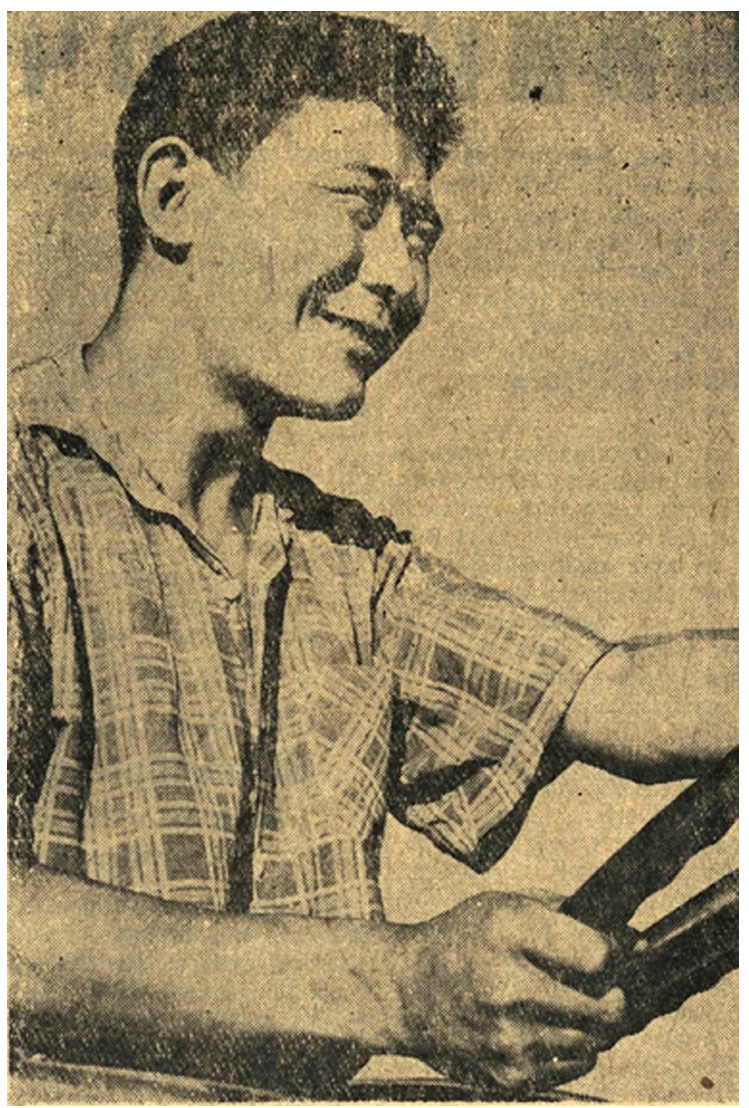

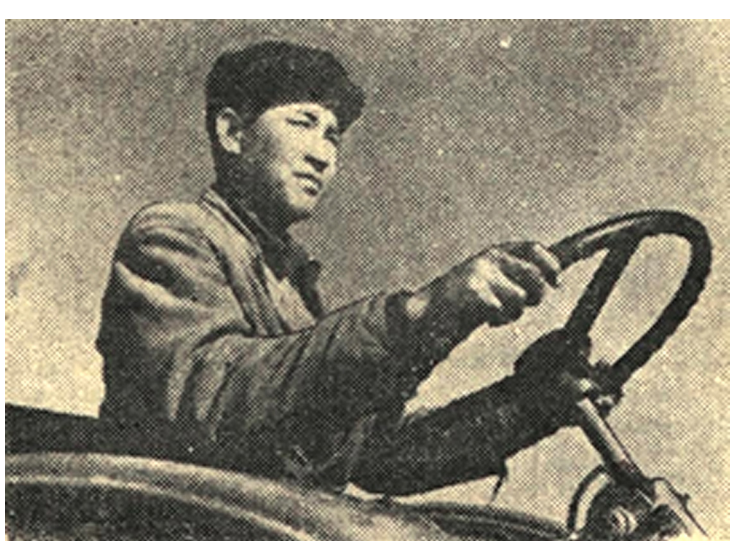

Фото 2.3. «Енотаевский» совхозин (Юстин район) сәәнәр көдлдг, өвс хадлһна зураһан давулж - 5,5 миңһн гектар һазрт өвс хадхин ормд 9 миңһн гектарт күргж хадсн тра́кторист Бембеев Сютюр. Автор неизвестен. = Лучший работник, тракторист совхоза «Енотаевский» (Юстинский район) Бембеев Сютюр, выполнивший план по заготовке сена (вместо запланированных 5,5 тыс. га довел площадь скошенных земель до 9 тыс. га) [Хальмг үнн 1958: № 223 (3207)]

[Photo 2.3. Syutuyr Bembeev, the best worker (tractor operator) of Yenotaevsky Sovkhoz (Yustinsky District) to have overfulfilled the haymaking plan (mowed 9,000 hectares of hay fields instead of the planned 5,500 hectares). Author unknown]

Фото 2.4. Үр Черхаровин һаржах Черноземельск района Полевой МЖС-н тракторн бригад эн жил зураһар кех көдлмшән 200 процент күргж күцәв. ЗУРГТ: эн бригадин нүүрлгч траторист үр Я. Горяев. У. Китляев цоксн зург $=$ Тракторная бригада тов. Черхарова из полевой МЖС (машинно-животноводческая станция) Черноземельского района довела выполнение годового плана до 200 процентов. На снимке: передовой тракторист этой бригады тов. Я. Горяев. Фото У. Китляева [Хальмг үнн 1961: № 181 (3935)]

[Photo 2.4. Ya. Goryaev, a leading driver of the tractor station. Comrade Cherkharov's tractor station affiliated to the Field-Based Motorized Livestock Station of Chernozemelsky District overfulfilled the annual plan by 100 percent. Photo by U. Kitlyaev] 


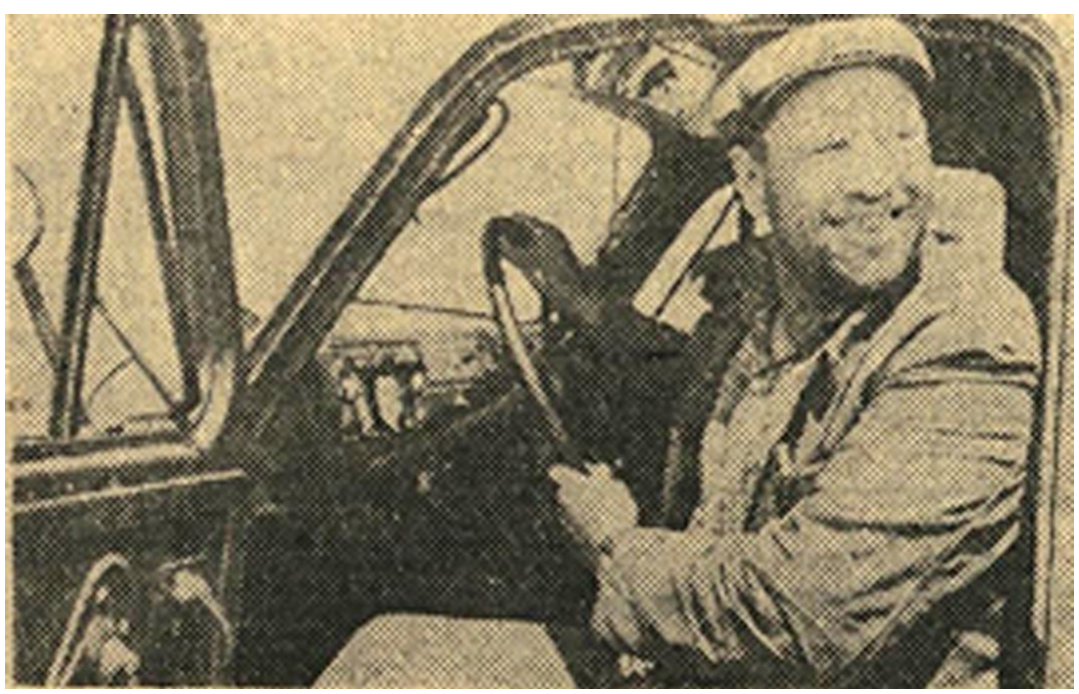

Фото 2.5. Сарпинск РТС-н щофер Н.Г. Тронев кезәд болвчн көдлмшән дигтә-тагтаһар күцәж, коллективдән ик тоомсрта йовна. Эн жил тәрә хуралһна гүргү цагла эн нег үлү шунж көдләд, кесг зун центнер будя государствин закрмур күргв. Ода эн шофер, авсн даалһвран партин XXII хург күртл күцәхәр шунж көдлжәнә. У. Китляевин цоксн зург = Шофер Сарпинского РТС (ремонтнотехническая станция) Н. Г. Тронев, всегда добросовестно выполняющий работу, пользуется большим уважением в коллективе. В разгар уборки урожая этого года он ударно работал и сдал в закрома родины несколько сот центнеров зерна. Сейчас шофер ударно работает, чтобы выполнить взятые обязательства до начала работы ХХІІ съезда КПСС. Фото У. Китляева [Хальмг үнн 1961:

№ 168 (3922)]

[Photo 2.5. N. Trotnev, a diligent and respectable driver of Sarpa Technical Service Station. In the heat of the harvesting campaign he delivered hundreds of centners of crops, and is currently working to fulfill the assumed commitments before the 22nd Congress of the CPSU begins. Photo by U. Kitlyaev]

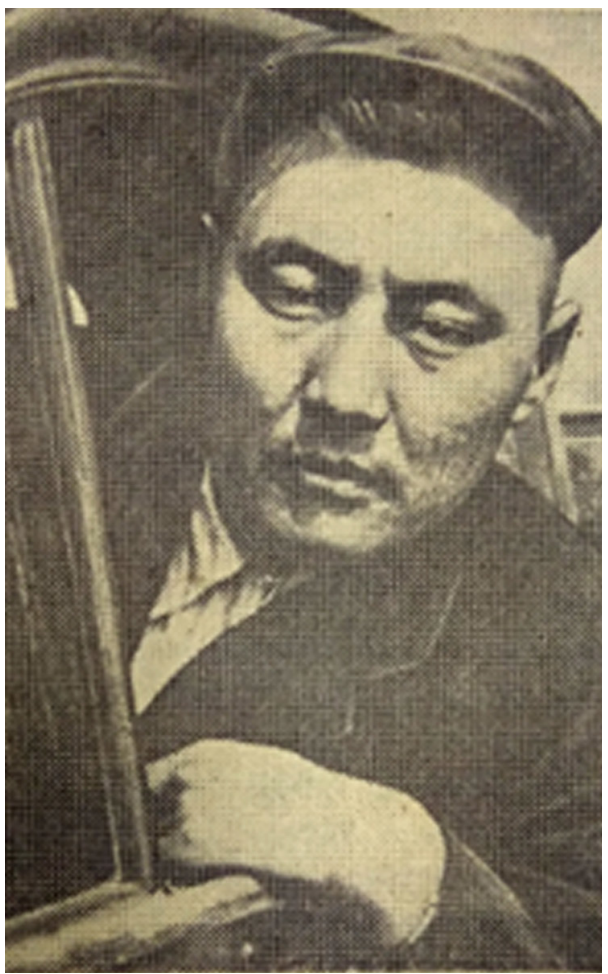

Фото 2.6. Яшалтинск района «Победа» гидг колхозин шофер Менкенасунов Михаил Лиджанович партин XXII хургиг күч-көлснә диилврәр тосхар гүжрж көдлжәнә. Тәрә хадж хуралһна цагла үр Менкенасунов комбайнас токур болн токас элеваторур 7010 центнер будя зөөв. ЗУРГТ: нүүрлгч шофер үр М. Л. Менкенасунов. В. Булановин цоксн зург = Ударно работает в социалистическом соревновании по достойной встрече XXII съезда КПСС шофер колхоза «Победа» Яшалтинского района Менкенасунов Михаил Лиджанович. Во время сбора урожая тов. Менкенасунов с комбайна на ток и с тока на элеватор перевез 7010 центнеров зерна. На снимке: передовой шофер тов. М. Л. Менкенасунов.

Фото В. Буланова [Хальмг үнн 1961: № 161 (3915)]

[Photo 2.6. M. Menkenasunov, a leading driver of Pobeda Kolkhoz (Yashaltinsky District) participating in the current Socialist competition to decently welcome the 22nd Congress of the CPSU. During the harvesting campaign, Comrade Menkenasunov transported a total of 7,010 centners of crops. Photo by V. Bulanov] 


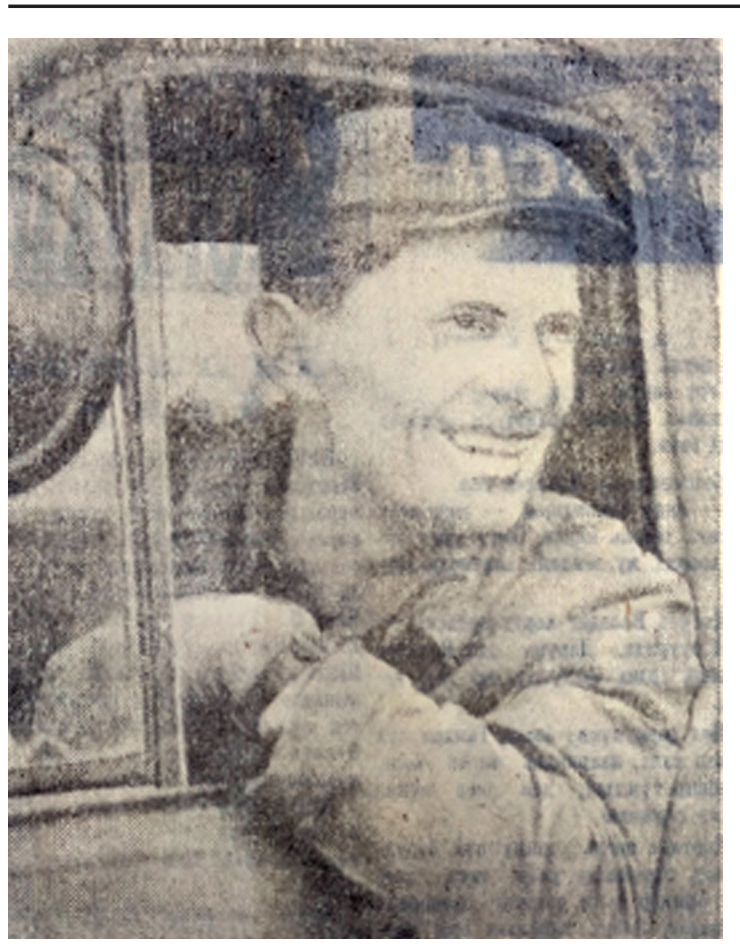

возможности больше удачных кадров, которые затем размещали в разных номерах газет (например, одну и ту же ситуацию запечатлевали с разных ракурсов в [Хальмг үнн: 1961: № 165 (3919), № 190 (3944), № 194 (3948), № 203 (3957)].

На страницах «Хальмг үнн», как и всякой региональной газеты в Советском Союзе, отражались не только события в республике, но также жизнь всей страны и важнейшие международные события. Об этом свидетельствует большое количество фотографий с сопроводительными текстами, присылаемых ТАСС, цель которых была отразить успехи внутренней и внешней политики Коммунистической партии, дать представление о недостатках жизни в капиталистических странах и преимуществах ее в странах социалистического лагеря. Противопоставление являлось любимым приемом советских фотожурналистов, обязанных показать превосходство социалистического образа жизни.

Фотографии отличались однотипностью композиции (например, фото 2.1-2.7), которая особенно заметна при просмотре большого количества снимков. Характерной чертой является также однотипность сюжетов. Самые распространенные сюжеты: водитель за рулем машины / трактора, доярка с ведром молока, пастух со стадом, че-
Фото 2.7. Яшкульск района 108 номертә совхозин шофер үр М. А. Кикоть эврәннь көдлж бәәх автомашиһәрн ясвр угаһар 80 миңһн километр кев, эн жилин һурвдгч кварталд 19 миңһн 305 километр йовб. Эн шофер көдлмштән цевр болн дигтә, энүнә «ГАЗ-51» машин даңгин бүрн-бүтн, көдлмшт белн бәәнә. ЗУРГТ: шофер үр М. А. Кикоть = Шофер совхоза № 108 Яшкульского района тов. М. А. Кикоть проехал 80 тыс. км на своей рабочей машине без ремонта, в третьем квартале этого года он проехал 19305 км. Этот шофер очень аккуратен в своей работе, его «ГАЗ-51» всегда находится в хорошем состоянии и готов к работе. На снимке: шофер тов. М. А. Кикоть [Хальмг үнн 1960: № 197 (3694)]

[Photo 2.7. M. Kikot, a driver at Sovkhoz 108 of Yashkulsky District whose vehicle has covered a total of $80,000 \mathrm{~km}$ without any essential breakdowns, including 19,305 $\mathrm{km}$ in the current third quarter. The driver is a neat worker and his GAZ-51 is always in going order]

ловек (люди) за чтением книги или газеты, сбор урожая, строитель на стройке и т. д. Расхожие сюжетные штампы были в традициях советской прессы и создавали полноту образа советского труженика: герой на работе, герой в отношениях с коллегами или друзьями, герой на отдыхе.

\section{Гиперболизация}

К гиперболизации прибегали многие советские фотожурналисты, как правило, для того, чтобы показать грандиозность строительства коммунизма. Фотокорреспонденты «Хальмг үнн» следовали тем же путем. В ходе анализа материала можно выделить три варианта гиперболизации: 1) на первом плане множественные объекты, а на втором - фигура человека (людей); 2) на первом плане фигура человека (людей), а на втором - множественные объекты; 3) на первом плане человек с тем или иным предметом больших размеров. Во всех этих вариантах советские люди, запечатленные на фотографиях, демонстрируют результат своей работы, высокие показатели в процессе строительства коммунизма. В первом и третьем вариантах в изображении приоритетен не сам процесс (порой нелегкий, осложненный трудностями), а его результат: на снимках показано, как рядовые труженики радуются достигнутому результату. Во 
Фото 3. Юстинск района Цаһан-Амн поселкин тетклһнә комбинатын колбас кедг цех эн жилин һурвн кварталын зураһан 145 процент күцәв. ЗУРГТ: колбас кедг цехин мастер Э. М. Сороков болн продукц хәләжәх цагнь. А. Вутеро цоксн зург = Колбасный цех комбината обслуживания пос. Цаган-Аман Юстинского района выполнил план третьего квартала этого года на 145 процентов. На снимке: мастер колбасного цеха Э. М. Сороков во время осмотра продукции. Фото А. Вутеро [Хальмг үнн 1961: № 234 (3988)]

[Photo 3. E. Sorokov, a sausage making shop foreman. The sausage making shop of Tsagan Aman Public Service Center (Yustinsky District) has exceeded the product plan of the third quarter by

45 percent. Photo by A. Vutero]

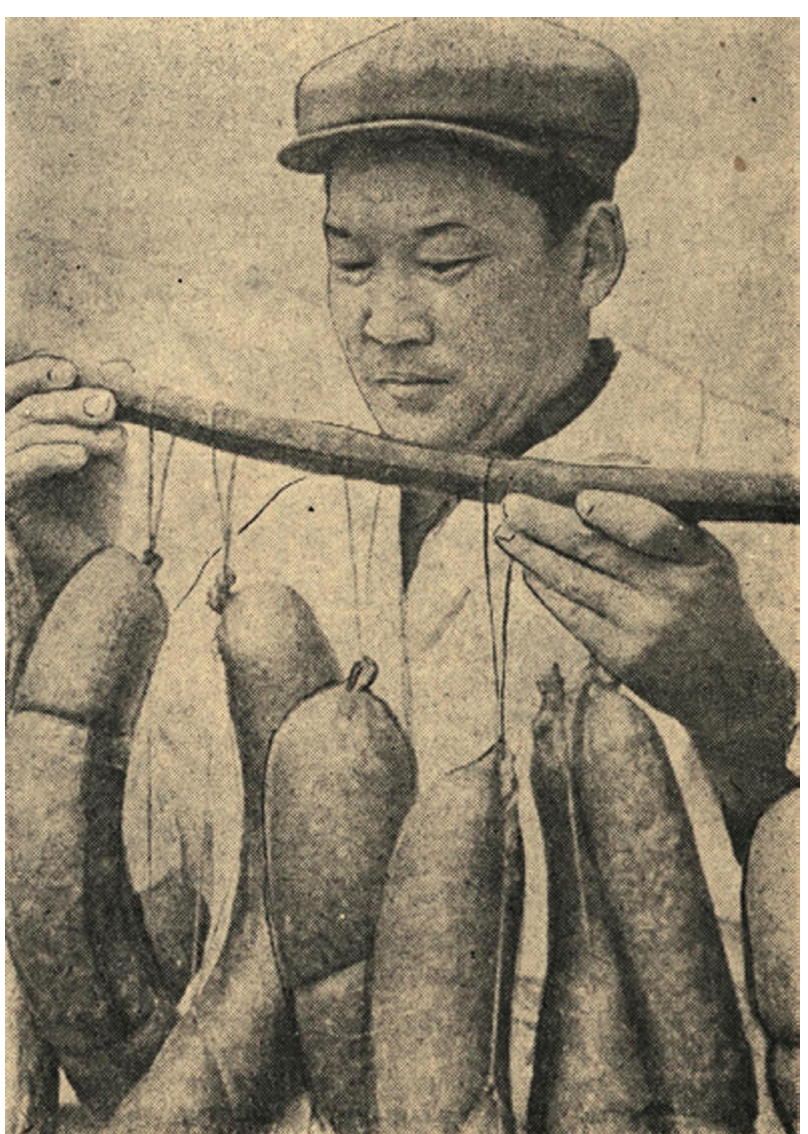

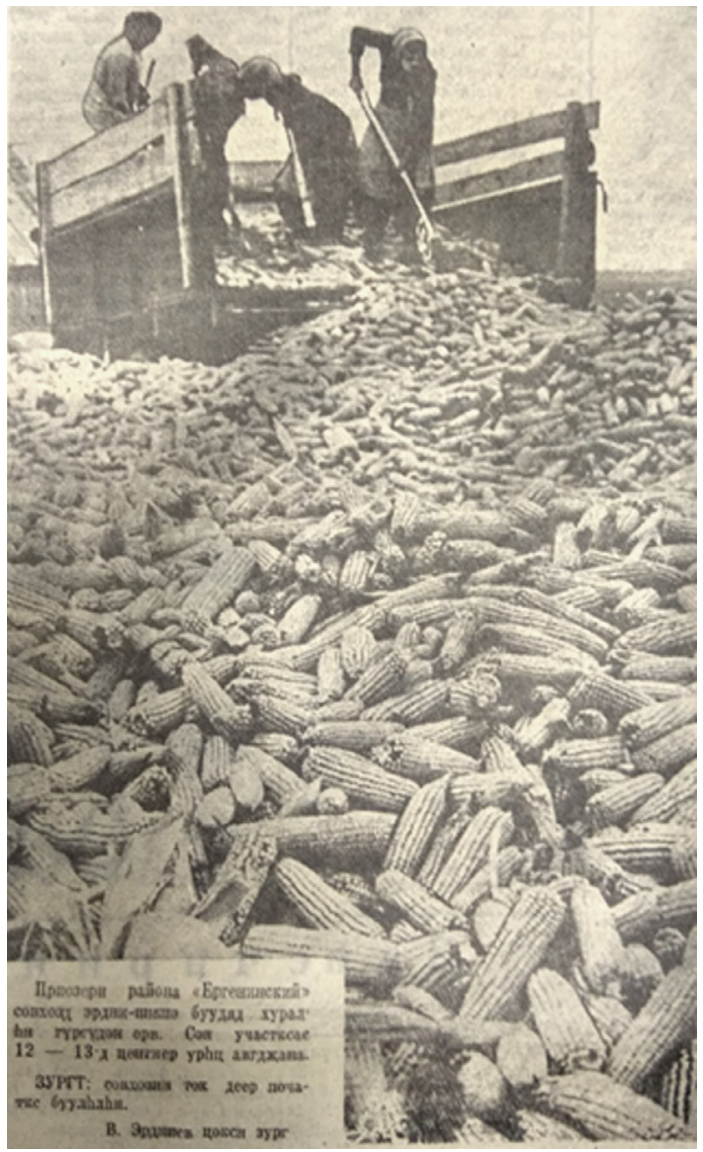

Фото 4.1. Приозерн района «Ергенинский» совхозд эрдни-шишә буудяд хуралһн гүргүдән орв. Сән участкас 12-13-д центнер урһц авгджана. ЗУРГТ: совхозин ток деер початкс буулһлһн. В. Эрдниев цоксн зург = Сбор урожая кукурузы в совхозе «Ергенинский» Приозерного района в разгаре. С хороших участков собрано по 13-14 центнеров урожая. На снимке: разгрузка початков кукурузы на совхозном току. Фото В. Эрдниева [Хальмг үнн 1961: № 194 (3948)]

[Photo 4.1. Discharge of corn cobs in process. In Ergeninsky Sovkhoz (Priozerny District) cropping of maize is at its height. The best fields have yielded up to 13-14 centners per hectare. Photo by V. Erdniev] 


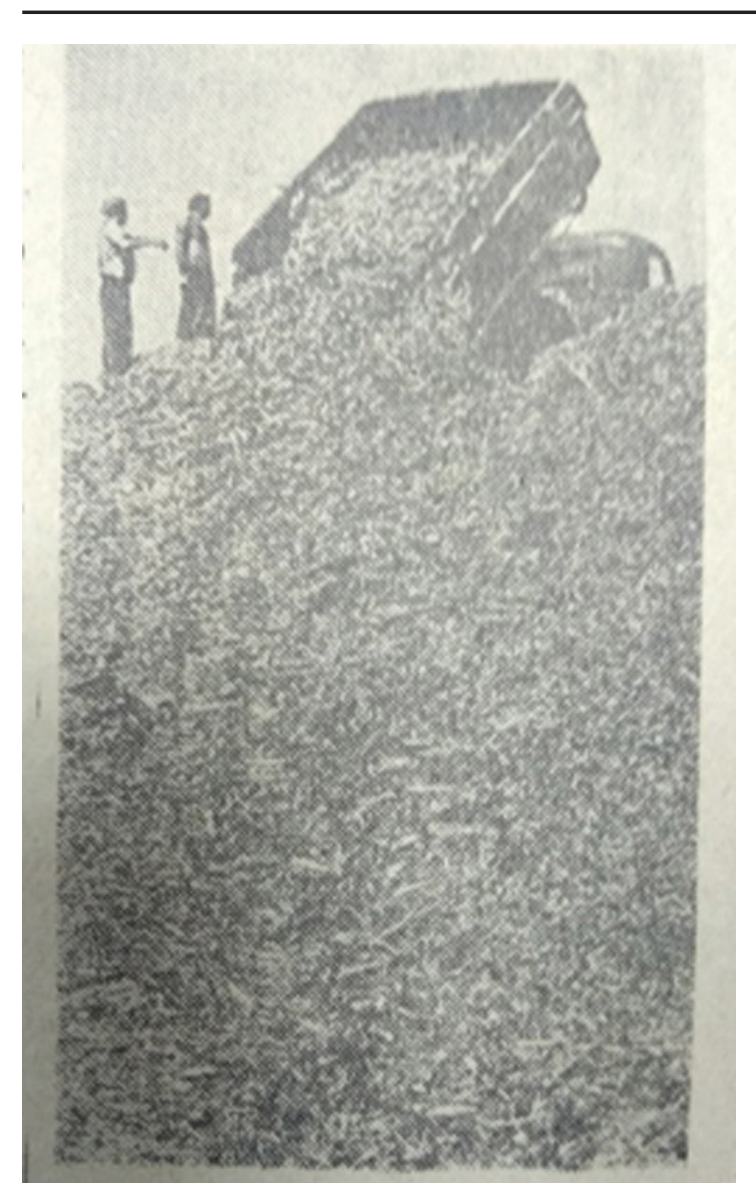

Фото 4.2. Сарпинск района «Гигант» колхозд эрдни-шишә силослһнд шин прогрессивн эв-арһ өргәр олзлгжана. ЗУРГТ: силост дарх көк урһмлиг ова деер самосвалар буулһжана. А. Вутерон цоксн зург = В колхозе «Гигант» Сарпинского района при силосовании кукурузы применяются новые прогрессивные методы. На снимке: зеленые растения для силосования разгружают с самосвала в кучу. Фото А. Вутеро [Хальмг үнн 1961: № 165 (3919)]

[Photo 4.2. To-be-ensilaged plants being discharged in a heap. Gigant Kolkhoz of Sarpinsky District employs advanced techniques to ensilage corn canes. Photo by A. Vutero]

втором варианте герои те же, но на их лицах нет уже лучезарных улыбок, наоборот, они очень серьезны и сосредоточены на своей работе. Происходит смешение стилей социалистического реализма и сурового стиля, которые сменили друг друга как раз в 60-е гг. XX в. (см. подробнее: [Алексеева, Виницкая 2017; Борев 2008; Бурганова 2008; Карпова 2015; Некрасова 2006]).

Ритмическая множественность объектов, как утверждает Л. В. Семова, является излюбленным приемом фотожурналисти- ки начиная с 1930-х гг. [Семова 2016: 71]. Поскольку Калмыцкая АССР имела сельскохозяйственную направленность, то объекты, которые были засняты в большом количестве, относятся к животноводству и растениеводству, хотя последнее практически не характерно для республики с аридным климатом.

Приведем в качестве примера несколько газетных фотографий.

На фотографиях 4.1-4.2 отражены моменты, связанные с насаждаемой Н. С. Хрущевым повсеместной высадкой «царицы полей» - кукурузы. Нужно отметить, что на страницах газеты можно найти множество фотографий, посвященных «кукурузной кампании».

На переднем фоне фотографии 4.1 мы видим початки кукурузы, на втором - машину, на которой стоят четыре человека и сбрасывают лопатами початки на землю. Кажется, что машина утопает в кукурузе. Лиц людей не видно, но очевидно, что на снимке три женщины и один мужчина. Работают они наравне, чем подчеркивается отсутствие деления на «женскую» и «мужскую» работу, характерное для советской эпохи. Применен необычный ракурс (который называют «родченковским», по фамилии знаменитого фотографа А. М. Родченко) - съемка снизу вверх, благодаря чему создано впечатление множества, богатого урожая, над которым, на втором плане, главенствуют крестьяне (которыми, заметим, калмыки никогда не были), чем подчеркивается их роль производителей, рачительных хозяев.

На фотографии 4.2 снят момент выгрузки зеленой массы, остающейся после сбора урожая кукурузы, причем люди, которые находятся рядом с машиной, кажутся крошечными, но они приподняты на верхний уровень сгружаемой кучи. Здесь также использован ракурс снизу, который опять же подчеркивает изобилие, богатство урожая, полученного тружениками села. Примененный ракурс усиливает композицию, целью которой является показать приподнятое настроение людей в ходе выполняемой работы.

На фотографиях 5.1-5.3 на первом плане - труженики, а на втором - множество домашних животных (овец или птиц). 


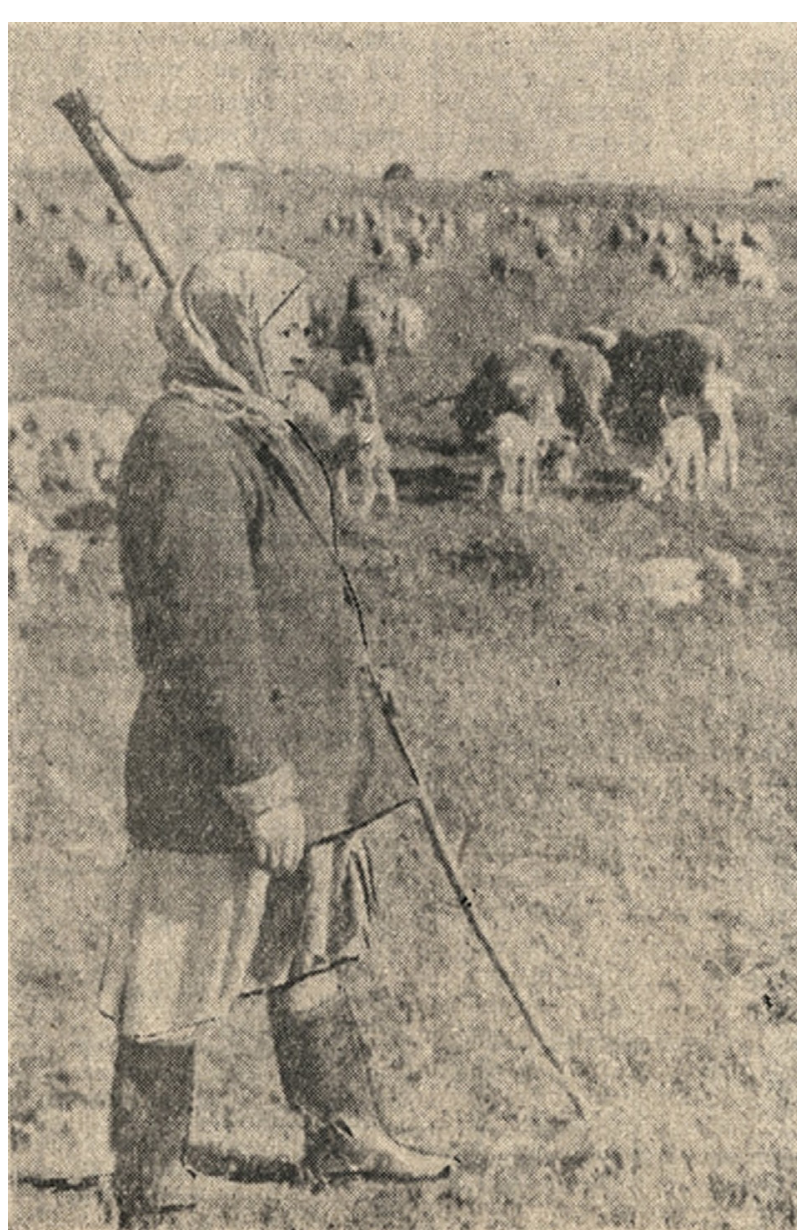

Фото 5.1. Городовиковск района «Южный» совхозин ах хөөч И. Светличныйин һаржах бригадт сакманщик болж А. П. Сангаджиева көдлжәнә. Өдгә цагт хәләжәсн хөөднь экләд хурһлжана. Авгджах төлиг hару угаһар эрүл-менд хадһлхар сакманщиц А. Сангаджиева көдлмштән цуг оньган өгч көдлжәнә. ЗУРГТ: А. П. Сангаджиева. У. Китляев цоксн зург = В бригаде старшего чабана совхоза «Южный» Городовиковского района И. Светличного работает сакманщицей А. П. Сангаджиева. Начинается окот овец, за которыми она ухаживает в настоящее время. Сакманщица А. Сангаджиева уделяет все свое внимание своей работе, чтобы сохранить без потерь приплод. На снимке: А. П. Сангаджиева. Фото У. Китляева [Хальмг үнн 1961: № 235 (3988)]

[Photo 5.1. A. Sangadzhieva, a sakman attendant who works in the crew headed by I. Svetlichny, a senior shepherd at Yuzhny Sovkhoz (Gorodovikovsky District). Comrade Sangadzhieva pays utmost attention of hers to guarantee that all newborn lambs survive. Photo by U. Kitlyaev]
Используется упоминавшийся выше прием съемки множественных объектов, применяемый ради эффекта гиперболизации достигнутых тружениками результатов. В данном случае множественными объектами являются те домашние животные, которые разводились в колхозе, совхозе или на птицеферме. Цель фотографий - создать впечатление, что деятельность этих хозяйств создает блага для советского человека. Но в них уже проступают черты сурового стиля. На первый план выходит сам труженик, труд которого нелегок. Лица людей сосредоточены, они заняты своей работой, на лицах нет наигранных улыбок, нет ложного энтузиазма и пафоса. Читатель должен увидеть на фотографии не идеологизированных и мифологизированных персонажей, а реальных, обычных людей.

На фотографии 6, где изображен бригадир овощеводческой бригады, мы также наблюдаем прием гиперболизации, применяемый часто в фотоматериалах тех лет. Фотокорреспондент намеренно изображает выращенный плод свеклы крупным планом, применяя фотографирование через стекло снимает выращенный плод свеклы широкоугольным объективом. Созданный оптический эффект - некоторого увеличения изображения на переднем плане - заставляет работать данный образ в контексте описания к фото, создавая определенные эмоции, в данном случае восхищения успехами аграриев.

\section{Выводы}

Исследование показывает, что в стилистике фотографий на страницах газеты «Хальмг үнн» («Калмыцкая правда») отражается смешении стиля социалистического реализма и сурового стиля. За первые два года рассматриваемого периода (1957-1961 гг.) фотография в калмыцкой прессе совершенствовалась в ускоренном темпе, редакционные фотографы быстро осваивали известные на тот момент в советской фотожурнали- 


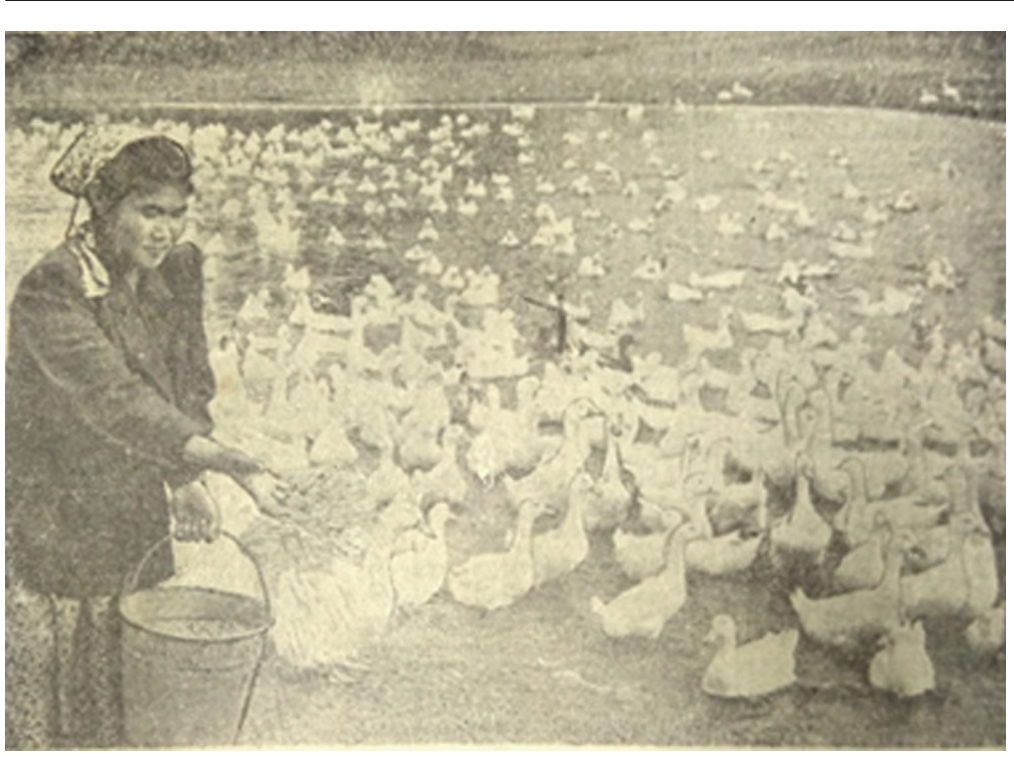

Фото 5.2. Сарпинск района «Степной» совхозин ПТФ-н шовуч Азыдова Евдокия Ховыковна партин XXII хург секгдтл 885 нуhс болн 2 миңһн һуумжл асрж өскәд махнд орулж өгхәр эн жилин хаврар даалһвр авла. Ода эврәннь асржах шовудан махнд орулж өгхд белдчкв. ЗУРГТ: Е. Х. Азыдова шовуд хотлжана. У. Китляевин цоксн зург = Птичница ПТФ (птицетоварная ферма) совхоза «Степной» Сарпинского района Азыдова Евдокия Ховыковна к открытию XXII съезда взяла повышенные обязательства вырастить и сдать к лету этого года 885 уток и 2 тысячи утят. Сейчас она приготовила к сдаче на мясо выращиваемых птиц. На снимке: Е. Х. Азыдова кормит птиц. Фото У. Китляева [Хальмг үнн 1961: № 188 (3942)]

[Photo 5.2. E. Azydova, a poultry-raiser at Stepnoy Sovkhoz of Sarpinsky District, feeding ducks. Evdokia Azydova assumed enhanced commitments to raise and deliver for slaughter a total of 885 ducks and 2,000 ducklings. Photo by U. Kitlyaev]

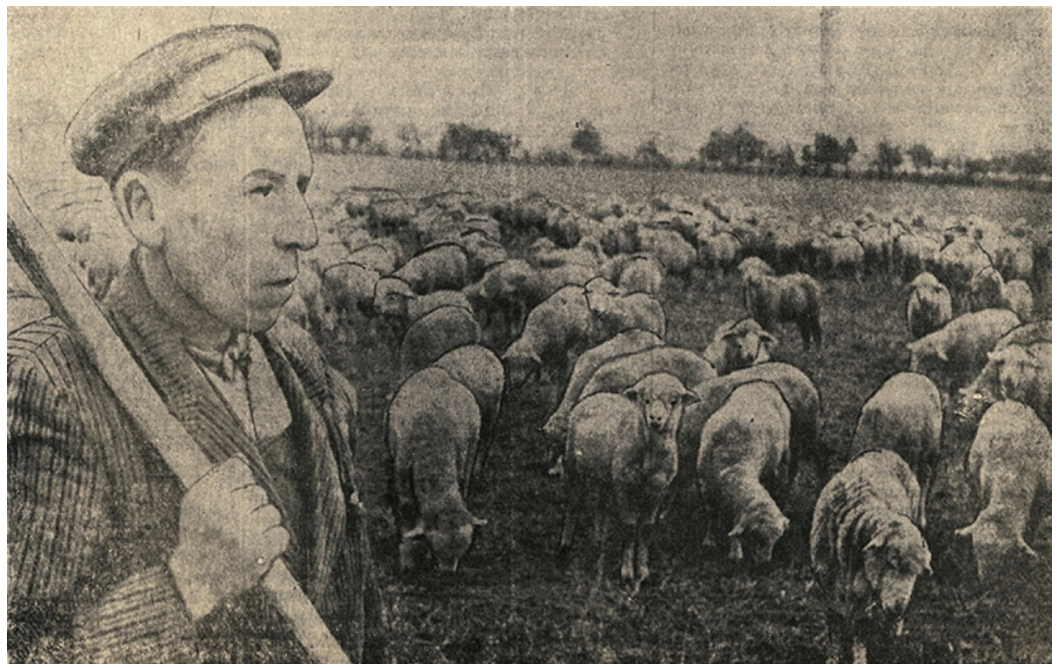

Фото 5.3. Городовиковск района «Пролетарская победа» колхозин ах хөөч M. М. Шматкон бригад 2460 хөөг һурвн отарт бәрж хәләжәнә. Зурһан күүнәс бүрдсн эн бригад хөөдән хойр жилд һурв дәкж хурһлуллһна дамшлт сөрж хәләсмн. Бригадин көдлмшнь сән ашта болв - зун хөн болһнас 224 хурһ эдн авцхав. Хөн болһнасн зураһар 5,2 килограмм ноос кирһхин ормд 5,7 килограмм ноос кирһж авб. ЗУРГТ: ах хөөч

М. М. Шмытко хөөдән хәрүлж йовх цагнь. У. Китляевин цоксн зург = Бригада старшего чабана колхоза «Пролетарская победа» Городовиковского района М. М. Шматко содержит в трех отарах 2460 овец. Бригада из шести человек планирует провести опыт получения приплода трижды за два года. Работа бригады дала положительные результаты — с каждой сотни овец получили по 224 ягненка. Вместо 5,2 кг получено 5,7 кг шерсти с каждой овцы. На снимке: старший чабан М. М. Шмытко во время пастьбы овец. Фото У. Китляева [Хальмг үнн 1961: № 228 (3982)]

[Photo 5.3. M. Shmytko, a senior shepherd at Proletarskaya Pobeda Kolkhoz. His crew successfully tends for a total of 2,460 sheep distributed across three flocks. The current animal yield is 224 lambs per 100 ewes; and 5,7 kg of fleece — instead of the planned 5,2 kg — per sheep. Photo by U. Kitlyaev] 


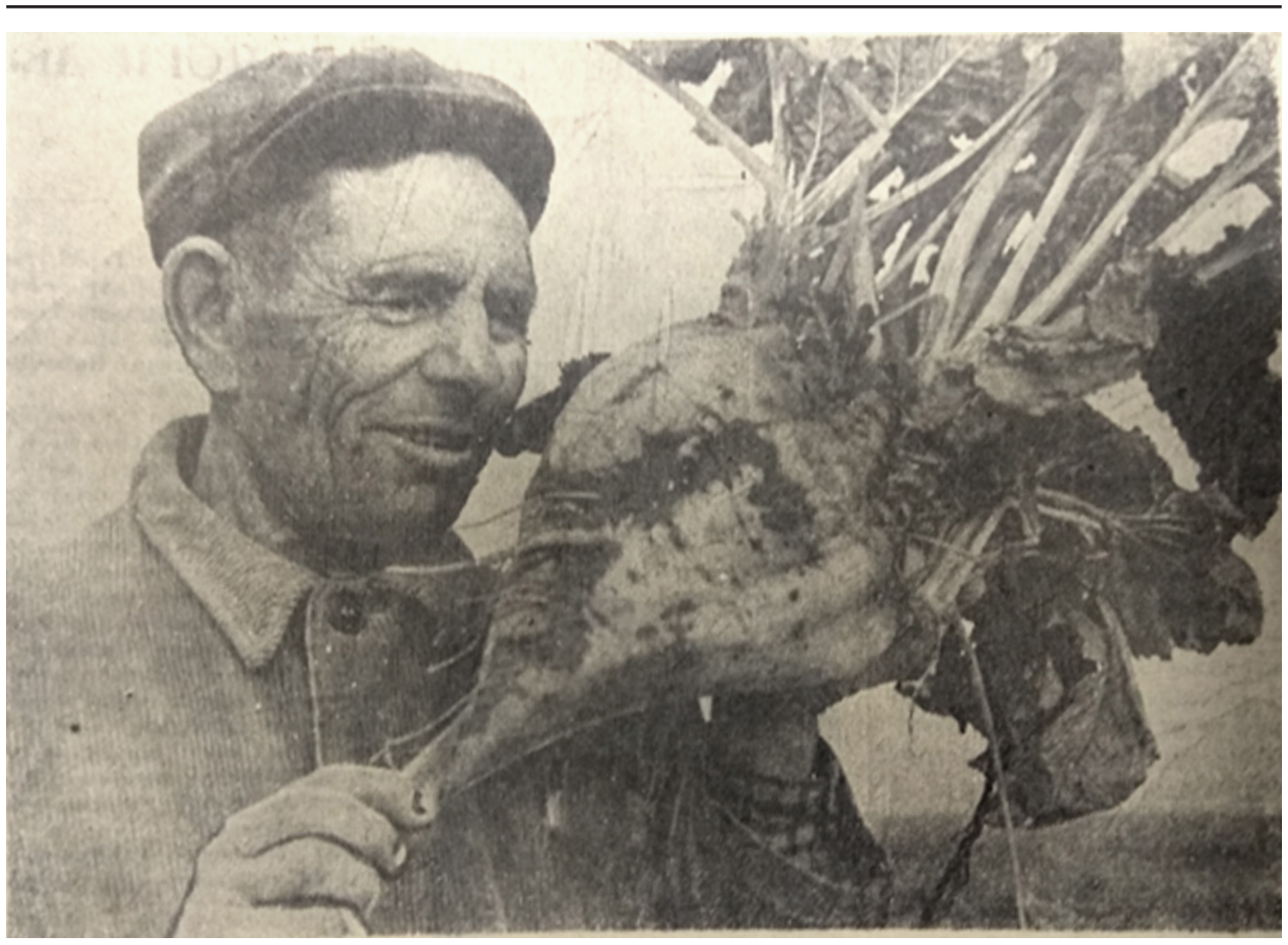

Фото 6. Каспийск района «Оленичевский» совхозин негдгч номертә һарудин бригадт бригадир болж Степан Данилович Остроухов 14 жил көлджәнә. Энүнә һардврар эн жил энд түрүн болж шикрин свекл тәргдв. Урһцнь йир сән болж - свекл болһн 3-5 килограмм татна. ЗУРГТ: бригадир С. Д. Остроухов шикрин свекл хәләжәх цагнь. А. Вутеро цоксн зург = В первой бригаде совхоза «Оленичевский» Каспийского района в течение 14 лет работает бригадиром Степан Данилович Остроухов. Под его руководством в этом году впервые посадили сахарную свеклу. Урожай был хорошим - каждая свекла весит 3-5 кг. На снимке: бригадир С. Д. Остроухов осматривает сахарную свеклу. Фото А. Вутеро [Хальмг үнн 1961: № 225 (3979)]

[Photo 6. S. Ostroukhov, the foreman of crew one at Olenichevsky Sovkhoz (Kaspiysky District), examining a sugar beet. Comrade Ostroukhov has been working as foreman for 14 years, and this year has witnessed the first yield of sugar beet planted by his crew, each root weighing up to 3-5 kg. Photo by A. Vutero]

стике приемы. Например те, с помощью которых достигалась гиперболизация изображаемого на снимках, востребованная советской идеологией. Гиперболизация достигалась съемкой с использованием определенных ракурсов, с помощью широкоугольного объектива и насадочных линз. В фокусе внимания фотожурналистов оказалась жизнь рядовых труже- ников, не являвшихся представителями партии и власти, прежде всего ее рабочие моменты. В анализируемых фотосюжетах несомненно влияние эпохи Н. С. Хрущева. Подобный анализ газетного материала необходимо продолжать в рамках изучения развития как региональной прессы, так и источника для антропологических исследований. 


\section{Источники}

Хальмг үнн - Хальмг үнн // НА КалмНЦ РАН. Полнотекстовая база данных газетного корпуса Республики Калмыкия. 1957-1961. // URL: http://biliq.ru/ethnography/ (дата обращения: 01.09.2020).

\section{Литература}

Алексеева, Виницкая 2017 - Алексеева T. П., Виницкая Н. В. Образы народа и судьбы индивидуальности в живописи сурового стиля // Культурное наследие Сибири. 2017. № 3 (21). C. 40-45.

Алексеева 2019 - Калмыки. Депортация. Возвращение / отв. ред. С. Э. Лиджи-Горяева. Элиста: ИКИАТ, 2019. 512 с.

Батырева 2020 - Батырева С. Г. Живопись и графика П. И. Емчегировой 1930-1950-х гг. (по материалам музейных и частных коллекций) // Oriental Studies. 2020. Т. 13. № 5. C. 1378-1388. DOI: 10.22162/2619-09902020-51-5-1378-1388

Борев 2008 - Борев Ю. Б. Социалистический реализм: взгляд современника и современный взгляд. М.: Изд-во АСТ, 2008. 478 с.

Бурганова 2008 - Бурганова М. А. Суровый стиль. Прямая речь // Дом Бурганова. Пространство культуры. 2008. № 1. С. 8-33.

Гучинова 2019 - Гучинова Э.-Б. М. У каждого своя Сибирь. Две истории о депортации калмыков (интервью с С. М. Ивановым и С. Э. Нарановой) // Oriental Studies. 2019. T. 13. № 3. C. 397-422. DOI: 10.22162/26190990-2019-43-3-397-422

Данилко, Александров 2020 - Данилко E. С., Александров Е. В. Визуальная антропология в России: от советского этнографического кино до современных исследований. Введение к специальной теме номера // Сибирские исторические исследования. 2020. № 4. С. 8-12.

\section{References}

Alekseeva T. P., Vinitskaya N. V. Images of people and the fate of individuality in the painting severe style. Kul'turnoe nasledie Sibiri. 2017. No. 3 (21). Pp. 40-45. (In Russ.)

Batyreva S. G. Painting and graphic works of P. I. Emchegirova, 1930s-1950s: a case study of museum and family collections. Oriental Studies. 2020. Vol. 13. No. 5. Pp. 1378-1388.

\section{Sources}

Khalmg Ünn. Collected newspaper issues. On: Newspaper Corpus of Kalmykia, 1957-1961. Full-Text Database. Kalmyk Scientific Center of the RAS, Scientific Archive. Available at: http://biliq.ru/ethnography/ (accessed: September 1, 2020). (In Kalm. and Russ.)

Карпова 2015 - Карпова К. В. Суровый стиль. Судьба направления: автореф. дис. ... канд. искусствовед. М., 2015. 22 с.

Кольцов 2005 - Кольизов П. М. Археологические исследования У. Э. Эрдниева // Профессор У. Э. Эрдниев: научное наследие / под ред. Г. М. Борликова. Элиста: Изд-во КалмГУ, 2005. С. 35-55.

Куканова и др. 2019 - Куканова В. В., Баянова А. Т., Долеева А. О., Каджиев А. Ю., Бадмаева M. Л. Национальная газета «Хальмг үнн» («Калмыцкая правда»): опыт анализа повседневности (на материале фотографий 1957-1959 гг.) // Oriental Studies. 2019. № 6. С. 1107-1118. DOI: 10.22162/26190990-2019-46-6-1107-1118

Некрасова 2006 - Некрасова E. C. Социалистический реализм как культурный феномен: автореф. дис. ... канд. философ. наук. СПб., 2006. $26 \mathrm{c}$.

Очиров 2019 - Очиров У. Б. Вместо введения // Калмыки. Депортация. Возвращение / отв. ред. С. Э. Лиджи-Горяева. Элиста: ИКИАТ, 2019. С. 12-31.

Семова 2016 - Семова Л. В. История отечественной фотожурналистики: учебное пособие: в 3 ч. Часть III: Советская фотография 1950-1980-х гг. М.: Фак-т журн. МГУ, 2016. $264 \mathrm{c}$.

Убушиева 2013 - Убушиева М. К. Моя жизнь, моя судьба. Элиста: ЗАОр «НПП „Джангар“», 2013. 88 с.

(In Russ.) DOI: 10.22162/2619-0990-2020-515-1378-1388

Borev Yu. B. Socialist Realism in the Eyes of Its Contemporary: A Contemporary Perspective. Moscow: AST, 2008. 478 p. (In Russ.)

Burganova M. A. The 'severe style'. Direct speech. Dom Burganova. Prostranstvo kul'tury. 2008. No. 1. Pp. 8-33. (In Russ.)

Danilko E. S., Aleksandrov E. V. Visual 
anthropology in Russia: from Soviet ethnographic filmmaking to contemporary visual research. Siberian Historical Research. 2020. No. 4. Pp. 8-12. (In Russ.)

Guchinova E.-B. M. 'Everyone has one's own Siberia': two stories of the Kalmyk deportation (interviews with S. M. Ivanov and S. E. Naranova). Oriental Studies. 2019. Vol. 13. No. 3. Pp. 397-422. (In Russ.) DOI: 10.22162/2619-0990-2019-43-3-397-422

Karpova K. V. The Severe Style: Destiny Revisited. Cand. Sc. (art studies) thesis abstract. Moscow, 2015. 22 p. (In Russ.)

Koltsov P. M. Archaeological investigations of U. E. Erdniev. In: Borlikov G. M. (ed.) Professor U. E. Erdniev and His Scientific Heritage. Elista: Kalmyk State University, 2005. Pp. 35-55. (In Russ.)

Kukanova V. V., Bayanova A. T., Doleeva A. O., Kadzhiev A. Yu., Badmaeva M. L. National newspaper Khalmg Ünn ('Kalmyk Pravda'): analyzing everyday life (a case study of photographs of 1957-1959). Oriental Studies. 2019. No. 6. Pp. 1107-1118. (In Russ.) DOI: 10.22162/2619-0990-2019-46-6-1107-1118

Lidzhi-Goryaeva S. E. (ed.) The Kalmyks. Deportation. Return. Elista: Institute for Comprehensive Studies of Arid Territories, 2019. 512 p. (In Russ.)

Nekrasova E. S. Socialist Realism as a Cultural Phenomenon. Cand. Sc. (philosophy) thesis abstract. St. Petersburg, 2006. 26 p. (In Russ.)

Ochirov U. B. Instead of the Introduction. In: Lidzhi-Goryaeva S. E. (ed.) The Kalmyks. Deportation. Return. Elista: Institute for Comprehensive Studies of Arid Territories, 2019. Pp. 12-31. (In Russ.)

Semova L. V. History of National Photojournalism. In 3 vols. Vol. III: Soviet Photography, 1950s-1980s. Moscow: Moscow State University, 2016. 264 p. (In Russ.)

Ubushieva M. K. My Life, My Destiny. Elista: Dzhangar, 2013. 88 p. (In Russ.) 